\title{
Influence of rosuvastatin treatment on airway inflammatory markers and health related quality of life domains in asthmatic patients
}

\author{
Astımlı hastalarda rosuvastatin tedavisinin havayolu inflamatuvar belirteçleri ve yaşam kalitesi \\ göstergeleri üzerine etkisi
}

Sehnaz OLGUN YILDIZELI, Derya KOCAKAYA, Baran BALCAN, Aygun IKINCI, Rengin AHISKALI, Berrin CEYHAN

\begin{abstract}
Objectives: Statins are lipid lowering agents which have pleiotropic and anti-inflammatory effects. Beneficial effects of statins have been shown in many inflammatory and asthmatic diseases. However, the results are still not consistent. The aim of this study is to determine the clinical and anti-inflammatory effects of rosuvastatin in asthmatic patients.

Patients and Metods: A case control study among asthmatic patients was conducted. One hundred and thirty-six participants were screened. Seventy-four patients were eligible. Fifty-one patients have completed the trial. Twenty-five patients with blood levels of low-density-lipoprotein (LDL) above $130 \mathrm{mg} / \mathrm{dL}$, were treated with rosuvastatin $40 \mathrm{mg}$ for 8 weeks in addition to their standard treatment for asthma; 26 asthmatic patients were followed as control group. In both groups baseline and $8^{\text {th }}$ week evaluation were recorded including pulmonary function test (PFT), bronchial provocation test (PD20), induced sputum and serum inflammatory markers, asthma control test (ACT) and quality of life scores (QoL).

Results: Statin group showed improvement in FEV1/FVC (pp) $(85.8 \pm 11.1 \%$ vs $90.2 \pm 8.8 \% P<0.043)$, FEF $25-75 \%(63.6 \pm 7.8 \%$ vs $74.6 \pm 8.4 \%, P<0.0001)$ and $\mathrm{FEF} 25-75(\mathrm{~L} / \mathrm{sc})(3.51 \pm 0.4$ vs $4.1 \pm 0.4$ $P<0.05)$ and no change was seen in non-statin group $(P>0.05)$ at the end of the 8-week treatment. Treatment with rosuvastatin resulted in decreased sputum eosinophilia percentage $(P<0.05)$; IL-6 and TNFalpha levels $(P<0.05)$ however, bronchial challenge test, ACT and QoL domains did not change in both groups $(P>0.05)$.

Conclusion: An 8-week treatment with $40 \mathrm{mg}$ rosuvastatin in asthma decreased the peripheral eosinophilia, total IgE levels and inflammatory markers in the induced sputum samples. Beneficial effects in PFT have also been observed. However, ACT and QoL domains were not affected. The implication of this study is that rosuvastatin could potentially have anti-inflammatory effects on asthmatic airways. Prospective randomised trials to evalute the clinical effects of rosuvastatin are warranted.

Keywords: Asthma, Airway inflammation, Remodelling, Rosuvastatin, Statin
\end{abstract}

Sehnaz Olgun Yildizeli (®), Derya Kocakaya, Berrin Ceyhan

Department of Pulmonary and Critical Care Medicine, School of Medicine,

Marmara University Hospital, Pendik, Istanbul, Turkey

e-mail:drsehnazolgun@yahoo.com

Baran Balcan

Department of Pulmonary Medicine, School of Medicine, Baskent University, Altunizade, Istanbul, Turkey

Aygun Ikinci, Rengin Ahiskali

Department of Pathology, School of Medicine, Marmara University Hospital, Pendik, Istanbul, Turkey

Submitted / Gönderilme: 05.02.2017

Accepted/Kabul: 04.04.2017
ÖZ

Amaç: Statinler kan lipid düzeylerinde azalma sağlamakla beraber aynı zamanda pleiotropik ve anti-inflamatuvar etkileri olan ilaçlardır. Statinlerin bir çok inflamatuvar hastalıkta yararlı etkileri gösterilmiş olmasına karşın sonuçlar halen tartışmalıdır. Bu çalışmanın amacı astım hastalarında rosuvastatin tedavisinin klinik ve anti-inflamatuvar etkilerini incelemektir.

Hastalar ve Yöntem: Astım hastalarında vaka-control çalışması planlanmıştır. Toplam 136 astım hastası incelenmiş ve 74 hasta çalışmaya uygun bulunarak dahil edilmiştir. Elli bir hasta çalışmayı tamamlayabilmiştir. Hastalar başlangıçta yapılan kan tahlilinde serum düşük dansiteli lipoprotein (LDL) seviyesine göre iki gruba ayrılmıştır, LDL düzeyi $130 \mathrm{mg} / \mathrm{dL}$ üzerinde olan 25 hasta mevcut tedavilerine ek olarak 8 hafta boyunca $40 \mathrm{mg}$ rosuvastatin tedavisi alırken, 26 hasta kontrol grubu olarak almakta oldukları tedaviye devam etmişlerdir. Her iki gruptaki hastalar, başlangıçta ve 8 . haftanın sonunda solunum fonksiyon testi (SFT), bronş provokasyon testi (PD20), indükte balgamda serum inflamatuvar belirteçleri, astım kontrol testi (AKT) ve yaşam kalitesi skorları $(\mathrm{QoL})$ ile değerlendirilmişlerdir.

Bulgular: Statin kullanan grupta 8. hafta sonunda SFT'de FEV1/ FVC (pp) $(\% 85,8 \pm 11,1$ vs . $\% 90,2 \pm 8,8 \quad P<0,043)$, FEF \% 25-75 $(\%$ $63,6 \pm 7,8$ vs $\% 74,6 \pm 8,4, P<0.0001)$ ve FEF $25-75(\mathrm{~L} / \mathrm{sc})(3,51 \pm 0,4$ vs $4,1 \pm 0,4 P<0,05)$ düzelme saptanırken statin kullanmayan grupta anlamlı fark saptanmamıştır $(P>0,05)$. Rosuvastatin tedavisi ile indükte balgam eosinofilisinde $(P<0,05)$; IL-6 ve TNF-alfa seviyelerinde azalma $(P<0,05)$ saptanırken, AKT ve QoL skorları ve bronş provakasyon testinde anlamlı değişiklik saptanmamıştır.

Sonuç: $\mathrm{Bu}$ çalışmada, astım hastalarında rosuvastatin $40 \mathrm{mg}$ ile 8 haftalık tedavi sonrasinda periferik eosinofili, total IgE seviyesi, indükte balgamda inflamatuvar belirteçlerde anlamlı düzeyde azalma saptanmıştır. Yine SFT parametrelerinde düzelme izlenmiştir ancak buna karşın AKT ve QoL skorlarında değişim saptanmamıştır.Bu sonuçlara göre rosuvastatin tedavisinin astım hastaları üzerinde bir takım potensiyel anti-inflamatuar etkileri bulunmaktadır. Rosuvastatinin klinik etkilerinin saptanması için daha fazla sayıda randomize çalışmaya ihtiyaç vardır.

Anahtar kelimeler: Astım, Havayolu inflamasyonu, Remodeling, Rosuvastatin, Statin 


\section{Introduction}

Asthma, a common global health problem, remains as one of the most prevalent chronic inflammatory airway diseases with a trend of increase in both prevalence and annual cost. It has been strongly associated with bronchial hyperreactivity and airway remodelling. Frequent hospitalization, emergency department visits, and early deaths still have been reported despite guideline-depended treatments. It is the fact that novel managements are needed to control asthma.

The statins have been known to decrease the blood cholesterol levels by inhibiting 3-hydroxy-3-methylglutaryl coenzyme $A$ which is the rate-limiting enzyme of cholesterol synthesis [1]. Additionally, it has been demonstrated that statins exhibit anti-inflammatory and immunomodulatory effects. The pleiotropic anti-inflammatory actions have been shown in several diseases. Previous studies have reported that statin use in asthmatic population decreases sputum eosinophilia [2], use of asthma medications, asthma related hospitalization and emergency department visits $[3,4]$. Furthermore, some studies have reported that statin therapy improves quality of life (QoL) scores in asthmatics, [5], whereas some others have failed to replicate these results $[6,7]$ thus the potential therapeutic role of statins related to anti-inflammatory action in asthma remains an open question.
In the current study, we aimed to assess the impact of statin treatment on pulmonary function test (PFT) including bronchial challenge test inflammatory and allergic markers, asthma control test (ACT) and QoL.

\section{Patients and Methods}

\section{Subjects}

This case-control study was conducted between December 2009 and March 2011 at the Asthma Clinic of our hospital among asthmatic patients as defined by the global initiative for asthma (GINA) guidelines [8]. The study was approved by the University Ethics Committee (MAR-YC-2009-0009) and all patients provided written informed consent prior to participation.

Inclusion criteria were; age of patients between 18-80 years old, known asthmatic patients according to the GINA criteria; positive methacholine challenge test and no history of anti-hyperlipidemia treatment. The exclusion criteria were; pregnancy, any medical contraindication for usage of statins, diagnosis of chronic obstructive pulmonary disease (COPD), history of cancer and history of smoking $>10$ pack-years. As shown in Figure 1, 136 consecutive patients with known asthma were eligible. Among them, 24 were excluded due to negative methacholine test, and 38 were

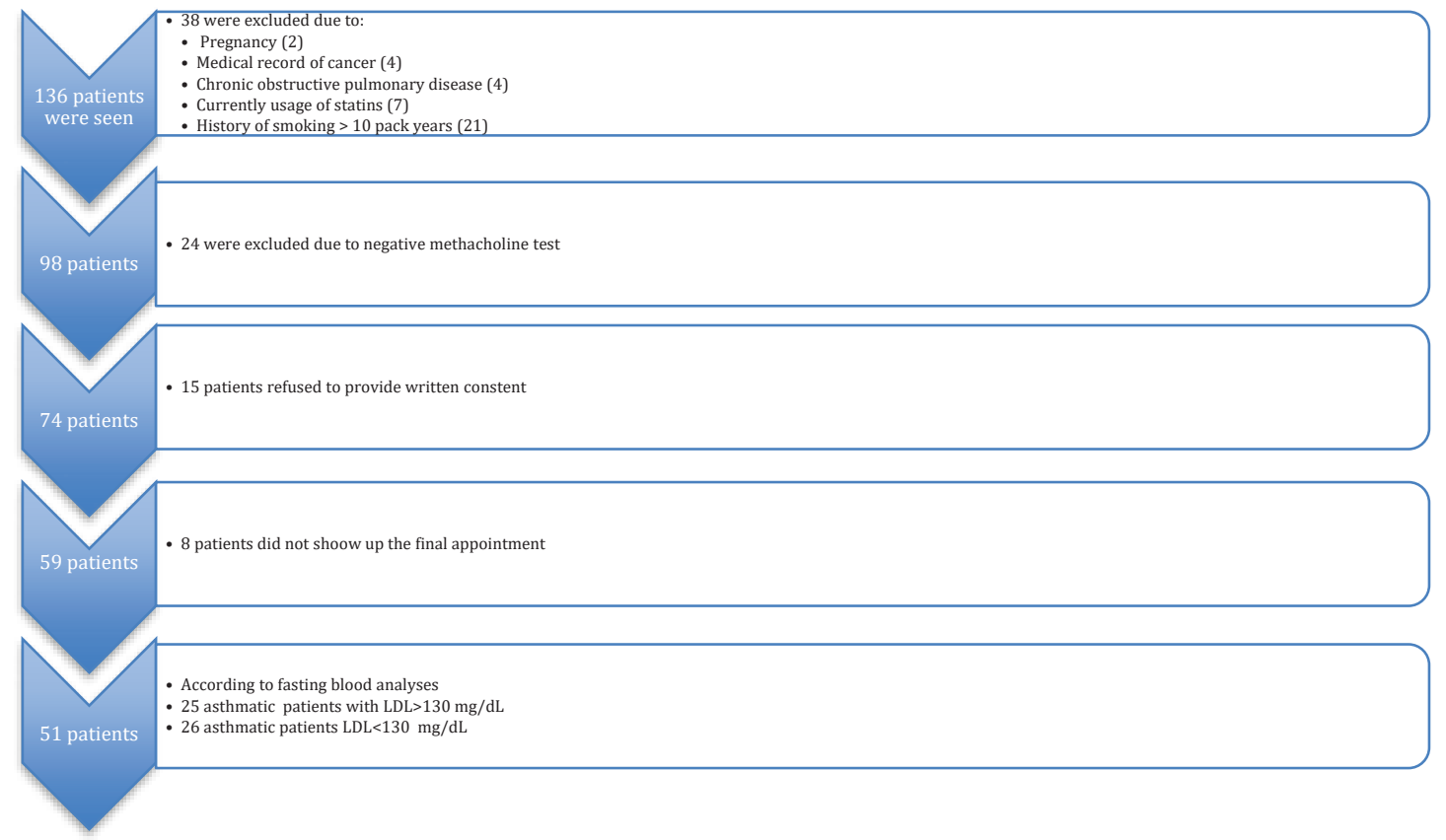

Figure I: Consort diagram of subjects 
excluded due to the other exclusion criteria described above. Fifteen individuals refused to provide an informed consent and 8 asthmatics did not come to the final appointment. Thus, 51 patients constituted the final study population (Figure I).

\section{Group assignment}

The cases were the asthmatic patients with $\mathrm{LDL} \geq 130 \mathrm{mg} / \mathrm{dL}$ $(\mathrm{n}=25)$, who were given $40 \mathrm{mg}$ rosuvastatin treatment daily in addition to standard asthma therapy. The control group was the asthmatic patients with LDL $<130 \mathrm{mg} / \mathrm{dL} \quad(\mathrm{n}=26)$ who were given standard asthma treatment. Both groups were evaluated at baseline and after 8 weeks.

\section{Measurements}

Patients underwent physical examination and spirometry according to the American Thoracic Society criteria [9] in order to assess the forced expiratory volume in 1 second $\left(\mathrm{FEV}_{1}\right)$ and other parameters of PFT (MIR Spirolab II Italy). A methacholine bronchial provocation test was performed with Koko dosimeter (Devilbiss 626) using a standardized technique [10]. We also assessed current medication use (inhaler corticosteroids [ICS]), long-acting beta-2 agonists, leukotriene receptor antagonist and oral steroids) and whether the patient had been hospitalised or treated in the emergency department for asthma in the previous year.

Positive skin prick test was defined as a wheal diameter $\geq 3 \mathrm{~mm}$ in response to aeroallergens (SAY ILAC, Turkey). $\operatorname{IgE}$ levels were evaluated using the chemiluminescent immunometric method in Immulite 2000 (Siemens Healthcare Diagnostics, USA). A total IgE level >100 IU/L was defined as high. Peripheral eosinophilia was determined on peripheral blood smear (patients categorized as having eosinophilia if $\geq 3 \%$ ).

We assessed asthma control and life quality using the Turkish translation of the ACT and QoL Questionnaire. In the ACT, a score of 19 or less was used to define poor control [11]. A change at least 0.5 in the QoL Questionnaire was of clinical relevance.

\section{Sputum induction and processing}

The induced sputum was assessed according to European Respiratory Society guideline criteria [13]. All subjects produced an adequate aliquot of sputum, which was produced within termination of the induction. Cell smear preparations were made using a cytospin cytocentrifuge (500g force, two minutes). Gram staining was used to differentiate cells and counts within the sputum cytospin slides, conducted by a cytologist to identify 400 nonsquamous cells. The supernatant was stored -80 degrees C for subsequent assay for IL-2 (Dia Source KAP1241, Nivelles- Belgium), IL-4 (Dia Source KAP1281, NivellesBelgium), IL-6 (Dia Source KAP1261, Nivelles- Belgium), IL-8 (Dia Source KAP1301, Nivelles- Belgium), IL-10 (Dia Source KAP1321, Nivelles- Belgium), TNF-alpha (Dia Source KAP1751, Nivelles-Belgium). Concentrations were determined using the Enzyme Amplified Sensitivity Immunassay method.

\section{Statistical analysis}

Changes were described as delta within groups (8 weeks vs baseline) and compared with paired t-test, respectively. Delta changes between groups were compared with unpaired t-test. All descriptive variables between groups were compared with the chi-square test. Due to the wide range of PD20 values of methacholine provocation test, logarithmic $(\log 10)$ transformation was performed. For the evaluation of association between inflammatory cells and cytokine levels in sputum and lung function parameters, ACT and QoL scores, Spearman correlation test was used. A $p$ value of less than 0.05 was considered significant. Primary sample size calculation was based on assumption that mean $\mathrm{FEV}_{1}$ would increase by approximately $0.10 \mathrm{~L} /$ $\sec ( \pm 0.12 \mathrm{~L} / \mathrm{sec})$ with 23 patients in the statin group with $80 \%$ power at the 0.05 level.

\section{Results}

\section{Demographic findings}

As illustrated in Figure 1, 51 patients constituted the final study population (25 statin group vs 26 non-statin group). Female-to-male ratio was $23 / 2$ and $25 / 1$, and mean age was $45.6 \pm 9.1$ in statin group and $42.8 \pm 9.4$ in non-statin group $(P>0.05)$. Asthma severity (severe $3.9 \%$, moderate $33.7 \%$ and mild $62.7 \%$ ) was comparable between groups. There was no statistical difference between the groups regarding, comorbidities and medication (Table I). 
Table I; Patient demographics, disease characteristics and medication

\begin{tabular}{lccc}
\hline & $\begin{array}{c}\text { Statin group } \\
(\mathrm{n}=25)\end{array}$ & $\begin{array}{c}\text { Non-statin group } \\
(\mathrm{n}=26)\end{array}$ & $P$ Value \\
\hline Diagnosis of comorbid diseases & 6 & 4 & $>0.05$ \\
Positive skin prick test & 14 & 16 & $>0.05$ \\
Mild asthma & 15 & 12 & $>0.05$ \\
Moderate asthma & 9 & 12 & $>0.05$ \\
Severe asthma & 1 & 2 & $>0.05$ \\
ICS** & 3 & 2 & $>0.05$ \\
ICS+LABA*** & 22 & 24 & $>0.05$ \\
Oral Steroid & 1 & 1 & $>0.05$ \\
\hline
\end{tabular}

*: Congestive Heart Failure and/or Diabetes Mellitus and/or Chronic Renal Failure

**: Inhaled corticosteroid

***: Inhaled corticosteroid + Long acting beta-agonist

$* * * *$ : Leukotriene receptor antagonist

\section{Pulmonary function test}

As shown in Table II, there was no statistical difference between the groups at baseline regarding the PFT results. No significant change in $\mathrm{FEV}_{1}$, but significant improvements in $\mathrm{FEV}_{1} / \mathrm{FVC}(\%)(85.8 \pm 11.1$ vs $90.2 \pm 8.8), \mathrm{FEF}_{25-75}$ pp (\%) (63.6 \pm 7.8 vs 74.6 \pm 8.4 and $\mathrm{FEF}_{25-75}(\mathrm{~L} / \mathrm{sec})(3.51 \pm 0.4$ vs $4.1 \pm 0.4)$ were observed in the statin group at the end of 8 weeks (Table II). No significant changes were observed in the non-statin group. Between-group differences regarding delta change from baseline reached the significance level for $\mathrm{FEF}_{25-75} \mathrm{pp}$ and $\mathrm{FEF}_{25-75}(\mathrm{~L} / \mathrm{sec})$.

\section{Bronchial challenge test}

Mean PD20 provocation dose increased from $4.1 \pm 2.8 \mathrm{mg} / \mathrm{ml}$ to $5.1 \pm 3.4 \mathrm{mg} / \mathrm{ml}(P>0.05)$ in the statin group and decreased from $6.4 \pm 3.7 \mathrm{mg} / \mathrm{mL}$ to $5,2 \pm 3 \mathrm{mg} / \mathrm{mL}$ in the non-statin group $(P>0.05)$ however, these changes were not significant (Table III).

\section{Sputum cells and peripheral eosinophilia}

Baseline sputum eosinophil percentages were similar between groups, totally $62 \%$ of the patients had sputum eosinophilia $>\% 3$. Mean peripheral eosinophilia in the statin group showed a significant decline from $3.7+/-1.2 \%$ to $2.2+/-1.1 \%(P<0.05)$ while in the non-statin group there was no significant change (baseline: $2.9+/-1.2 \%$ vs $8^{\text {th }}$ week: $3+/-1.5 \%, P>0.05)$. These changes showed statistically significant differences between the two groups (statin group $\Delta=-1.5 \pm 1.4 \%$ vs non-statin group $\Delta=+0.7 \pm 1.3 \%$ ) $(P<0.05)$.

\section{Allergy parameters}

Total IgE levels showed a significant decline in the statin group $(P<0.05)$. However, in the non-statin group no significant change was observed. Prick test results did not change in both groups $(P>0.05)$, (Table III).

\section{Cytokines}

A significant decrease in the level of IL-6, and TNF- $\alpha$ was observed in the statin-group $(P<0.05)$ moreover, comparison of delta changes in both groups revealed a significant decrease in vascular endothelial growth factor (VEGF) and TNF- $\alpha$ levels $(P<0.05)$ (Table IV).

\section{ACT and QoL}

Both asthma control questionnaire and QoL questionnaire did not show any significant change at the end of the study period in both groups (Table III).

There was no documented side effect of statin. 
Table II; PFT results in statin and non-statin groups.

\begin{tabular}{|c|c|c|c|c|c|c|c|c|c|}
\hline & \multicolumn{4}{|c|}{ Statin group } & \multicolumn{4}{|c|}{ Non-statin group } & \multirow[b]{2}{*}{$\begin{array}{c}P \\
\text { value } \\
\text { †† }\end{array}$} \\
\hline & $\begin{array}{l}\text { Before } \\
\text { statin } \\
\text { treatment }\end{array}$ & $\begin{array}{l}\text { After } \\
\text { statin } \\
\text { treatment }\end{array}$ & $\begin{array}{l}\Delta \\
\text { change }\end{array}$ & $\begin{array}{l}\mathrm{p} \\
\text { value }\end{array}$ & Baseline & $\begin{array}{l}8 \text { weeks } \\
\text { later }\end{array}$ & $\begin{array}{l}\Delta \\
\text { change }\end{array}$ & $\begin{array}{c}P \\
\text { value } \\
\dagger\end{array}$ & \\
\hline FVC (L) & $3.02 \pm 0.6$ & $3.04 \pm 0.6$ & $1.6 \pm 9.8$ & 0.4 & $2.8 \pm 0.9$ & $2.8 \pm 0.9$ & $0.02 \pm 0.1$ & 0.4 & 0.2 \\
\hline $\mathrm{FEV}_{1}(\mathrm{pp}) \%$ & $90.4 \pm 11.1$ & $89.8 \pm 10.7$ & $-0.5 \pm 66$ & 0,6 & $80 \pm 18$ & $80,2 \pm 20.8$ & $0.1 \pm 6.1$ & 0.9 & 0.6 \\
\hline $\mathrm{FEV}_{1} \mathrm{~L} / \mathrm{sec}$ & $1.85 \pm 0.2$ & $1.82 \pm 0.2$ & $-0.1 \pm 1.1$ & 0.5 & $1.83 \pm 0.37$ & $1.82 \pm 0.4$ & $-0.1 \pm 0.9$ & 0.6 & 0.6 \\
\hline $\begin{array}{l}\mathrm{FEV}_{1} / \mathrm{FVC} \\
(\%)\end{array}$ & $85.8 \pm 11.1$ & $90.2 \pm 8.8$ & $\begin{array}{l}4.3 \pm 10 . \\
1\end{array}$ & 0.043 & $89.3 \pm 13$ & $88.8 \pm 12.5$ & $-0.4 \pm 10.6$ & 0.8 & 0.1 \\
\hline $\begin{array}{l}\text { FEF25-75 } \\
\text { (pp) }\end{array}$ & $63.6 \pm 7.8$ & $74.6 \pm 8.4$ & $11 . \pm 6.6$ & $\begin{array}{l}0.000 \\
1\end{array}$ & $61.7 \pm 13$ & $60.8 \pm 13.5$ & $-0.8 \pm 12.8$ & 0.7 & 0.000 \\
\hline $\begin{array}{l}\text { FEF25-75 } \\
(\mathrm{L} / \mathrm{sec})\end{array}$ & $3.51 \pm 0.4$ & $4.1 \pm 0.4$ & $0.4 \pm 1.1$ & 0.05 & $3.42 \pm 0.51$ & 3.39 & $-0.1 \pm 1.4$ & 0.6 & 0.001 \\
\hline
\end{tabular}

$\Delta$ change: Baseline vs 8 weeks statin treatment $\dagger p$ : Within-group comparison of data at baseline vs $8^{\text {th }}$ week (paired t-test), $\dagger \dagger \mathrm{p}$ : Between-group comparison of $\Delta$ change in statin group vs non-statin group (unpaired t-test)

Table III; ACT,quality of life scores and allergy test results.

\begin{tabular}{|c|c|c|c|c|c|c|c|c|c|}
\hline & & Statin group & & & & Non-s & tin group & & \\
\hline & $\begin{array}{l}\text { Before statin } \\
\text { treatment }\end{array}$ & $\begin{array}{l}\text { After statin } \\
\text { treatment }\end{array}$ & $\Delta$ change & $\begin{array}{l}P \\
\text { value }\end{array}$ & Baseline & $\begin{array}{l}\text { After statin } \\
\text { treatment }\end{array}$ & $\Delta$ change & $\begin{array}{l}P \\
\text { value } \\
\dagger\end{array}$ & $\begin{array}{l}P \\
\text { value } \\
\text { †† }\end{array}$ \\
\hline QoL & $127.7 \pm 31.5$ & $130.1 \pm 28.4$ & $2.4 \pm 22$ & 0.5 & $122.6 \pm 25$ & $124.8 \pm 29$ & $3 \pm 16$ & 0.3 & 0.9 \\
\hline $\begin{array}{l}\text { Total } \\
\text { IgE } \\
(\mathrm{IU} / \mathrm{L})\end{array}$ & $215.3 \pm 334.0$ & $\begin{array}{l}182.6 \pm 320 . \\
0\end{array}$ & $-32.6 \pm 233$ & 0.01 & $\begin{array}{l}125.9 \pm 11 \\
7.0\end{array}$ & $135.3 \pm 142$ & $9.4 \pm 40.7$ & 0.7 & 0.015 \\
\hline $\begin{array}{l}\text { Peripherl } \\
\text { eosinophi } \\
\text { lia (\%) }\end{array}$ & $3.7+/-1.2 \%$ & $\begin{array}{l}2.2+/-1.1 \\
\%\end{array}$ & $-1.5 \pm 1.4$ & $\begin{array}{l}<0.0 \\
5\end{array}$ & $\begin{array}{l}2.9+/- \\
1.2 \%\end{array}$ & $3+/-1.5 \%$ & $\begin{array}{l}0.7 \pm 1.3 \\
\%\end{array}$ & $>0.05$ & $<0.05$ \\
\hline $\begin{array}{l}\text { PD20 } \\
(\mathrm{mg} / \mathrm{ml})\end{array}$ & $4.1 \pm 2.8$ & $5.1 \pm 3.4$ & $5 \pm 19$ & $\begin{array}{l}>0.0 \\
5\end{array}$ & $6.4 \pm 3.7$ & $5.2 \pm 3$ & $-3 \pm 11$ & $>0.05$ & $>0.05$ \\
\hline
\end{tabular}

$\Delta$ change: Baseline vs 8 weeks statin treatment, $\dagger \mathrm{p}:$ Within-group comparison of data at baseline vs $8^{\text {th }}$ week (paired t-test)..

$\dagger+p$ : Between-group comparison of $\Delta$ Change in statin group vs non-statin group (unpaired t-test) 
Table IV; Inflammatory markers in group I and II (baseline, 8th week and change)

\begin{tabular}{|c|c|c|c|c|c|c|c|c|c|}
\hline & \multicolumn{4}{|c|}{ Statin Group } & \multicolumn{4}{|c|}{ Non-Statin Group } & \multirow[b]{2}{*}{$\begin{array}{l}P \\
\text { value } \\
\text { †† }\end{array}$} \\
\hline & Baseline & $\begin{array}{l}8 \text { weeks after } \\
\text { statin } \\
\text { treatment }\end{array}$ & $\begin{array}{l}\Delta \\
\text { Change }\end{array}$ & $\begin{array}{l}P \\
\text { value } \\
\dagger\end{array}$ & Baseline & $\begin{array}{l}8 \text { weeks after } \\
\text { statin } \\
\text { treatment }\end{array}$ & $\begin{array}{l}\Delta \\
\text { Change }\end{array}$ & $\begin{array}{l}P \\
\text { value } \\
\dagger\end{array}$ & \\
\hline $\begin{array}{l}\text { IL-6 } \\
(\mathrm{pg} / \mathrm{ml})\end{array}$ & $\begin{array}{l}18.7 \pm \\
23.4\end{array}$ & $9.9 \pm 37.2$ & $-8.7 \pm 40.5$ & 0.000 & $\begin{array}{l}24.3 \pm \\
23.5\end{array}$ & $6.7 \pm 8.7$ & $-17.5 \pm 24$ & 0.09 & 0.3 \\
\hline $\begin{array}{l}\text { IL-5 } \\
(\mathrm{pg} / \mathrm{ml})\end{array}$ & $\begin{array}{l}5.2 \pm \\
10.6\end{array}$ & $8.5 \pm 21.5$ & $3.2 \pm 19.9$ & 0.2 & $\begin{array}{l}10.5 \pm \\
32.8\end{array}$ & $4.4 \pm 14.5$ & $-6 \pm 31.9$ & 0.6 & 0.2 \\
\hline $\begin{array}{l}\text { IL-8 } \\
(\mathrm{pg} / \mathrm{ml})\end{array}$ & $\begin{array}{l}187,3 \pm \\
131\end{array}$ & $295,3 \pm 339$ & $107,9 \pm 356$ & 0,4 & $\begin{array}{l}272,2 \pm \\
321\end{array}$ & $272,9 \pm 257$ &, $8 \pm 395$ & 0,3 & 0,3 \\
\hline $\begin{array}{l}\text { IL-4 } \\
(\mathrm{pg} / \mathrm{ml})\end{array}$ & $\begin{array}{l}106,9 \pm \\
40.9\end{array}$ & $140.5 \pm 104.2$ & $33.1 \pm 112.9$ & 0.8 & $\begin{array}{l}113 \pm \\
38.4\end{array}$ & $142.6 \pm 74.8$ & $29.5 \pm 78.9$ & 0.3 & 0.8 \\
\hline $\begin{array}{l}\text { IL-10 } \\
(\mathrm{pg} / \mathrm{ml})\end{array}$ & $\begin{array}{l}20.8 \pm \\
26.7\end{array}$ & $13 \pm 19$ & $-8.0 \pm 32.3$ & 0.5 & $\begin{array}{l}14.6 \pm \\
21.6\end{array}$ & $14.4 \pm 23.5$ & $-0.2 \pm 27.2$ & 0.7 & 0.3 \\
\hline $\begin{array}{l}\text { TNF - } \\
\text { alpha } \\
(\mathrm{pg} / \mathrm{ml})\end{array}$ & $\begin{array}{l}0.91 \pm \\
1.1\end{array}$ & $0.22 \pm 0.7$ & $-0.7 \pm 0.8$ & 0.000 & $\begin{array}{l}0.38 \pm \\
1.2\end{array}$ & $0.15 \pm 0.4$ & $\begin{array}{l}- \\
0.22 \pm 1.37\end{array}$ & 0.5 & 0.007 \\
\hline
\end{tabular}

$\dagger \dagger P$ : Between-group comparison of $\Delta$ Change in statin group vs non-statin group (unpaired t-test)

\section{Discussion}

In this study, we evaluated the effects of statins in asthmatic patients. To our knowledge, this is the first study addressing the clinical and immune-modulatory effects of rosuvastatin together in asthmatics patients. Our study results have shown that a daily dose of $40 \mathrm{mg}$ rosuvastatin for a duration of 8 weeks is effective in decreasing the level of inflammatory markers such as TNF- $\alpha$, IL-6 in induced sputum samples, and it improved pulmonary function indices such as $\mathrm{FEV}_{1} /$ FVC (\%), $\mathrm{FEF}_{25-75}(\mathrm{pp})$ and $\mathrm{FEF}_{25-75}(\mathrm{~L} / \mathrm{sec})$, peripheral eosinophilia and total serum IgE in asthmatic patients. However, we did not find any statistically significant change in ACT, QoL assessments and bronchial challenge test with 8 weeks statin treatment.

Previous publications have reported the clinical efficacy of statin treatment in asthmatic patients. Inhibition of airway remodelling which is secondary to airway smooth muscle proliferation and contraction, goblet cell hyperplasia and blockage of inflammatory cell influx with depleted cytokines release are the most significant effects of statins on asthmatic airways [4]. According to Kwak et al., diminished amounts of eosinophils and macrophages after statin treatment are the proof of decreased airway inflammation [3]. The main surrogate markers of efficacy in these studies were change in respiratory symptoms and PFT values. However, these results are inconsistent. Several randomised controlled studies assessed the effects of statin treatment in asthmatic patients, and six of them did not show any improvement on PFT indices [2,5,14-17). On the other hand, a minor improvement in $\mathrm{FEV}_{1}(P<0.01)$ with simvastatin treatment and improvement in $\mathrm{FEV}_{1}$ and all day symptoms with atorvastatin therapy in severe asthmatics have been reported [18]. A recent retrospective study did not show a significant change in PFT of severe asthmatics with the usage of statins [4]. Moreover, mild-moderate asthmatic patients showed no significant change ( $\mathrm{FEV}_{1}$ and $\left.\mathrm{FVC}\right)$ with atorvastatin use [17]. However, patients in our study receiving statin treatment showed improvement in $\mathrm{FEV}_{1} / \mathrm{FVC}(\%), \mathrm{FEF}_{25-75}$ (pp) and $\mathrm{FEF}_{25-75}(\mathrm{~L} / \mathrm{sec})$. The discrepancy between previous and 
present findings can be attributed mainly to the difference in the clinical status of participants. Some of these studies showed that statins significantly improved clinical outcomes in severe asthmatics, however, the participants were mostly mild to moderate asthmatics in these studies similar to our study [20]. We also evaluated the effect of statin according to severity of the disease but improvement of PFT did not show any difference statistically, probably this would be related with inconvenient dispersal number of cases in each group.

Another point is the type of the statins that may affect the results; in our study we used rosuvastatin, which has been known to have more powerful pleiotrophic effects than other statins. Differences in dose and duration of drugs make it difficult to conclude that whether statins can improve lung functions or not. Additionally, we identified no significant effect of rosuvastatin treatment on mean methacholine provocation dose. Similar results have been reported with $20 \mathrm{mg}$ atorvastatin treatment for 4 weeks in 22 adult asthma patients compared with placebo group [21]. Contrary to these results, Menzies et al., showed increased metacholine provocation dose levels after 4 weeks simvastatin therapy in the absence of inhaled corticosteroids treatment, but no other improvement in PFT[15].

Asthmatic symptoms evaluated with ACT and QoL using $40 \mathrm{mg}$ atorvastatin for 4 weeks have shown improvement in scores, however this was not maintained at the $8^{\text {th }}$ week in a study [5]. Moreover, a recent study has identified higher adjusted mean ACT scores in severe asthmatics with the use of statins [4]. In contrast, these findings were not supported by others $[2,17,18]$. Similarly, in our study we also did not find any significant change in ACT and QoL scores after the 8 week statin therapy. This discrepancy may be due to usage of different statins and different duration period as well as different asthma severities.

Previously, it has been shown that statins have resulted in structural changes in $\operatorname{IgE}$ receptor, decreased $\operatorname{IgE}$ secretory functions, increased levels of anti-IgE activity and decreased mast cell degranulation $[22,23]$. The effect may differ based on the type of statin. Interestingly, a decrease in histamine levels were seen with cerivastatin and atorvastatin while it was not seen with simvastatin and pravastatin in a human mast cell line study [24]. Animal studies have also shown a decrease in $\operatorname{IgE}$ levels and inflammatory cells in bronchoalveolar lavage (BAL) specimens of asthmatic rats with simvastatin treatment [25]. Although, several studies did not show any effect of statin on peripheral eosinophilia
$[4,15,17]$ we found a decline of peripheral eosinophilia in asthmatic patients by using rosuvastatin. There is only one study which evaluated skin prick test and other atopic findings reported partly similar results with our results. They reported that statin usage did not effect IgE levels, skin prick test results and nasal polyp formation [26]. However, we have found a substantial effect of statin treatment on $\operatorname{IgE}$ levels. It is also possible that these discrepancies may result from differences in statins used and study duration. Overall, it is likely that statin may have a role in atopism, however, the clinical implications are not clear yet.

The underlying mechanism of statins on asthma is not clear. However, there are some possible mechanisms that may cause reduction in inflammation. Downregulation of gene expression and decreasing the stability of lipid raft formation both result in decreased release of cytokines and chemokines [2]. This proinflammatory cytokines IL-4, IL5 , IL-6, IL-13 and TNF- $\alpha$, trigger airway inflammation with different pathways [27]. IL-4 effects B cells with the production of IgE which is the important feature of mast cell activation and allergic inflammation, IL-5 increases the eosinophils production and IL-13 has a central role in IgE synthesis [28]. It is well-known that TNF- $\alpha$ has an important role in activation of neutrophils and eosinophils. It increases the cytotoxic ability of eosinophils and smooth muscle contractibility and potential to stimulate fibroblast and mesenchymal cells which is important for airway remodelling in asthma [29]. Studies on patients with asthma exacerbation have shown increased levels of TNF- $\alpha$ in BAL specimens also inhalation of TNF- $\alpha$ in healthy volunteers resulted in increased amounts of cytokine release and neutrophil in sputum samples [30]. Studies targeting TNF- $\alpha$ blockage resulted in the improvement of PFT and asthma symptom scores [31]. Epithelial remodelling in asthma is greatly influenced by TNF- $\alpha$ and IL-1 [32]. Recent studies have shown that statins have suppressive effects on macrophages, antigen presenting cells and natural killer cells (NK) also inhibiting leukocyte extravasation and cause decline in IL-1, IL-6 and TNF- $\alpha$ levels in cell lines [3]. A decrease in the levels of TNF- $\alpha$ in cell-lines with atorvastatin has been previously shown [33]. Further animal studies using ischemia models described the immune-modulatory effects of rosuvastatin by a decrease in the levels of TNF- $\alpha$, IL- 6 and IL-1 in serum and related organ tissues. Researchers proposed that increased levels of IL-10 were related with its anti-inflammatory effects [34]. Similar to the previous studies, we have found a decrease in the levels of IL-6, TNF- $\alpha$ with rosuvastatin in sputum sample of asthmatic 
patients. However, an increase in IL-10 levels was not observed. The discrepancy between our study, animal and in vitro studies may be related with the experimental antigen sensitization, and asthma model created mechanisms in animals differ from humans and different dosage in animal studies may be too high for humans. Also, in animal studies, inhaled form of statins are used that directly effect airways but in human studies statins given orally and extensively are absorbed by the liver [35]. In animal studies, despite shortterm statin treatment, positive results have been considered to be related with the drug doses and administration route of statins. Finally, patients were classified only according to their blood cholesterol levels in our study, but PFT, PD20 for metacholine provocation, total IgE levels, specific IgE numbers, eosinophil count and skin prick test results were similar at baseline. Therefore, it may be interpreted that serum cholesterol levels have no effect on the mentioned parameters and these results are in accordance with the previously mentioned large population screening study [35]. In this study, because of paucity of studies evaluating the effects of statins according to asthma phenotypes we did not classified patients as allergic, non-allergic, late onset or obese asthmatic.

Limiting factors of our study can be listed as higher rate of females and small number of severe asthmatics being included. Additionally, the lack of a group of patients with normal blood cholesterol levels being treated with statins is another drawback. Furthermore, the anti-inflammatory effect of statins are potentially due to the cholesterol lowering effects in hyperlipidemic subjects, is another source of debate. However, large population studies have shown no association of serum cholesterol levels with atopy [36]. Although, the anti-inflammatory effects of statins appear before their anti-hyperlipidemic effects, the time interval for anti-inflammatory effects of statins on airways has yet to be defined. In our study, the treatment duration of 8 weeks may not be sufficient for the all anti-inflammatory effects to be revealed. The heterogeneity of the study groups, medications, and doses in previous studies as well as their designs do not allow us to comment on which statin has the best effect.

\section{Conclusion}

In conclusion, an 8-week treatment with 40mg rosuvastatin in asthma decreased the peripheral eosinophilia, total $\operatorname{IgE}$ levels, and inflammatory markers seen in the induced sputum samples of asthmatics. Furthermore, beneficial effects in PFT have also been observed. However, these results did not translate to any improvement in ACT and QoL scores. Understanding the immune-modulatory effects of statins in asthma by studies designed in large number of patients may lead to the development of novel targeted interventions. A further long-term larger study with placebo control is warranted.

\section{Conflict of Interest: None}

Funding: This study was supported by Marmara University Medical Research Committee (BAPKO)

\section{References}

1. Corsini A, Maggi FM, Catapano AL. Pharmacology of competitive inhibitors of HMG-CoA reductase. Pharmacol Res 1995;31:9-27. doi: 1043-6618(95)80042-5

2. Hothersall EJ, Chaudhuri R, McSharry C, et al. Effects of atorvastatin added to inhaled corticosteroids on lung function and sputum cell counts in atopic asthma. Thorax 2008;63:1070-5. doi: 10.1136/thx.2008.100198

3. Kwak B, Mulhaupt F, Myit S, Mach F. Statins as a newly recognized type of immunomodulator. Nature Medicine 2000;6:1399-402. doi: 10.1038/82219

4. Zeki AA, Oldham J, Wilson M, et al. Statin use and asthma control in patients with severe asthma. BMJ Open 2013;3:e003314. doi: 10.1136/bmjopen-2013-003314

5. Braganza G, Chaudhuri R, McSharry C, et al. Effects of shortterm treatment with atorvastatin in smokers with asthma. A randomized controlled trial. BMC Pulm Med 2011;11:16. doi: 10.1186/1471-2466-11-6.

6. Christiansen SC, Eddleston J, Wagelie-Steffen A, Yang AJ, Chen W, Zuraw BL. Influence of HMC-CoA reductase inhibitors on asthma severity. J Allergy Clin Immunol 2009;123:No 2 S84 Abst 313

7. Ostroukhova M, Kouides RW, Friedman E. The effect of statin therapy on allergic patients with asthma. Ann Allergy Asthma Immunol 2009;103:463-8. doi: 10.1016/S10811206(10)60261-X

8. Report G. Global Initiative for Asthma:GINA Report, Global Strategy for Asthma Management and Prevention- updated 2012. 2012. Available at : (http://www.ginasthma.org). 2012 (Accessed:

9. Standardization of Spirometry, 1994 Update. American Thoracic Society. American Journal of Respiratory and Critical Care Medicine 1995;152:1107-36. doi: 10.1164/ ajrccm.152.3.7663792

10. Chai H, Farr RS, Froehlich LA, et al. Standardization of bronchial inhalation challenge procedures. J Allergy Clin Immunol 1975;56:323-7.

11. Schatz M, Sorkness CA, Li JT, et al. Asthma Control Test: reliability, validity, and responsiveness in patients not 
previously followed by asthma specialists. J Allergy Clinical Immunol 2006;117:549-56. doi: 10.1016/j.jaci.2006.01.011

12. Pinnock H, Sheikh A, Juniper EF. Evaluation of an intervention to improve successful completion of the MiniAQLQ: comparison of postal and supervised completion. Primary Care Respiratory Journal : Journal of the General Practice Airways Group 2004;13:36-41. doi: 10.1016/j. pcrj.2003.11.004

13. Efthimiadis A, Jayaram L, Weston S, Carruthers S, Hargreave FE. Induced sputum: time from expectoration to processing. Europ Respir J 2002;19:706-8.

14. Foumani S, Nejatifar F, Forghan Parast K, Heidarinejad S, Mortazhejri G. Effects of atorvastatin in asthmatic patients under treatment with high dose oral or inhaled steroid. (Abstract) European Respirotary Society Annual Congress, Barcelona, Spain, September 18-22, 2010. (372).

15. Menzies D, Nair A, Meldrum KT, Fleming D, Barnes M, Lipworth BJ. Simvastatin does not exhibit therapeutic antiinflammatory effects in asthma. J Allergy Clinic Immunol 2007;119:328-35 doi: 10.1016/j.jaci.2006.10.014

16. Fahimi F, Jamaati H, Taheri ZM, Fakharian A, Salamzadeh J. Does atorvastatin have effect on lung function and morbiditiy as add on therapy in asthmatic patients? Europ Respir J 2007:490s:2960.

17. Moini A, Azimi G, Farivar A. Evaluation of atorvastatin for the treatment of patients with asthma: a double-blind randomized clinical trial. Allergy, Asthma Immunol Res 2012;4:290-4. doi: 10.4168/aair.2012.4.5.290

18. Cowan DC, Cowan JO, Palmay R, Williamson A, Taylor DR. Simvastatin in the treatment of asthma: lack of steroid-sparing effect. Thorax 2010;65:891-6. doi: 10.1136/thx.2010.138990

19. Feschenko Y, Lashyna L, Kramarskaya N, Polianska M, Matvienko J. Clinical and functional effectiveness of atorvastatin in complex therapy of severe bronchial asthma. (Abstract) European Respiratory Society Annual Congress, Berlin, Germany, October 4-8 2009. [E4554].

20. Liu PY, Liu YW, Lin LJ, Chen JH, Liao JK. Evidence for statin pleiotropy in humans: differential effects of statins and ezetimibe on rho-associated coiled-coil containing protein kinase activity, endothelial function, and inflammation. Circulation 2009;119:131-8. doi: 10.1161/ CIRCULATIONAHA.108.813311

21. Malek Mohammad M, Fahimi F, Fakharian A, et al. Methacoline Challenge test as an evaluator of response to statins in bronchial hyperresponsiveness. Iranian $\mathrm{J}$ Pharmaceutical Res 2012;11:969-77.

22. Deanin GG, Cutts JL, Pfeiffer JR, Oliver JM. Role of isoprenoid metabolism in $\operatorname{IgE}$ receptor-mediated signal transduction. J Immunol 1991;146:3528-35.

23. Roche CM, Trimble ER, Ennis M. Effect of in vivo and in vitro lovastatin treatment on mast cell activation. Int Arch Allergy Immunol 1995;108:240-6.

24. Krauth MT, Majlesi Y, Sonneck K, et al. Effects of various statins on cytokine-dependent growth and IgEdependent release of histamine in human mast cells. Allergy 2006;61:281-8. doi: 10.1111/j.1398-9995.2006.00997.x

25. Kim DY, Ryu SY, Lim JE, Lee YS, Ro JY. Anti-inflammatory mechanism of simvastatin in mouse allergic asthma model. Eur J Pharmacol 2007;557:76-86. doi: 10.1016/j. ejphar.2006.11.027

26. Yilmaz F, Gunduz H, Arinc H, et al. Does the prevalence of nasal polyps increase in patients using statins? Adv Ther 2007;24:1330-9.

27. Kim YM, Kim YS, Jeon SG, Kim YK. Immunopathogenesis of allergic asthma: more than the th2 hypothesis. Allergy Asthma Immunol Res 2013;5:189-96. doi: 10.4168/ aair.2013.5.4.189

28. Kips JC. Cytokines in asthma. Eur Respir J Suppl 2001;34:24s-33s

29. Pennings HJ, Kramer K, Bast A, Buurman WA, Wouters EF. Tumour necrosis factor-alpha induces hyperreactivity in tracheal smooth muscle of the guinea-pig in vitro. Eur Respir J 1998;12:45-9.

30. Howarth PH, Babu KS, Arshad HS, et al. Tumour necrosis factor (TNFalpha) as a novel therapeutic target in symptomatic corticosteroid dependent asthma. Thorax 2005;60:1012-8. doi: 10.1136/thx.2005.045260

31. Berry MA, Hargadon B, Shelley M, et al. Evidence of a role of tumor necrosis factor alpha in refractory asthma. N Engl J Med 2006;354:697-708. doi:10.1056/NEJMoa050580

32. Camara J, Jarai G. Epithelial-mesenchymal transition in primary human bronchial epithelial cells is Smad-dependent and enhanced by fibronectin and TNF-alpha. Fibrogen Tiss Rep 2010;3:2. doi: 10.1186/1755-1536-3-2

33. Shyu KG, Chua SK, Wang BW, Kuan P. Mechanism of inhibitory effect of atorvastatin on resistin expression induced by tumor necrosis factor-alpha in macrophages. J Biomed Sci 2009;16:50. doi: 10.1186/1423-0127-16-50

34. Awad AS, El Sharif A. Immunomodulatory effects of rosuvastatin on hepatic ischemia/reperfusion induced injury. Immunopharmacol Immunotoxicol 2010;32:555-61. doi: $10.3109 / 08923970903575716$

35. Rubin BK. Statins for the treatment of asthma: a discovery well, dry hole or just snake oil. Thorax 2009;64:4-5. doi: 10.1136/thx.2008.106757

36. Fessler MB, Jaramillo R, Crockett PW, Zeldin DC. Relationship of serum cholesterol levels to atopy in the US population. Allergy 2010;65:859-64. doi: 10.1111/j.13989995.2009.02287.x 